\title{
Structure Of Chemically Prepared Amorphous Fe-B Particles
}

\author{
Mørup, Steen; Koch, C. Bender; Linderoth, Søren
}

Published in:

Digest of International Magnetics Conference

Publication date:

1993

Document Version

Publisher's PDF, also known as Version of record

Link back to DTU Orbit

Citation (APA):

Mørup, S., Koch, C. B., \& Linderoth, S. (1993). Structure Of Chemically Prepared Amorphous Fe-B Particles. In Digest of International Magnetics Conference IEEE.

\section{General rights}

Copyright and moral rights for the publications made accessible in the public portal are retained by the authors and/or other copyright owners and it is a condition of accessing publications that users recognise and abide by the legal requirements associated with these rights.

- Users may download and print one copy of any publication from the public portal for the purpose of private study or research.

- You may not further distribute the material or use it for any profit-making activity or commercial gain

- You may freely distribute the URL identifying the publication in the public portal

If you believe that this document breaches copyright please contact us providing details, and we will remove access to the work immediately and investigate your claim. 


\section{STRUCTURE OF CHEMICALLY PREPARED}

\section{AMORPHOUS Fe-B PARTICLES}

S. Mørup, C. Bender Koch, and S. Linderoth

Laboratory of Applied Physics, Technical University of Denmark, DK-2800 Lyngby.

The chemical reduction of metal salts in aqueous solution by borohydride is an interesting reaction for production of ultrafine amorphous boron-alloy particles. Amorphous transition metal-boron alloy particles prepared in this way have received much attention in recent years [1-5], both due to fundamental interest in their properties and their possible technological applications. The amorphous $\mathrm{Fe}_{1 \cdot-\mathrm{B}} \mathrm{B}_{\mathrm{x}}$ alloy particles discussed here have been prepared by chemical reduction of $\mathrm{Fe}^{2+}$ to the metallic state in aqueous solutions by the use of $\mathrm{NaBH}_{4}$.

After the preparation the particles easily burn when exposed to air. Two procedures are used to avoid this: the particle slurry is either frozen, or the particles are passivated by drying the slurry at room temperature in a flow of $\mathrm{N}_{2}$ or $\mathrm{Ar}$, containing some ppm $\mathrm{O}_{2}$

The Mössbauer spectra of frozen and passivated particles differ by the presence of a doublet in the spectra for the passivated sample at room temperature and an extra magnetically split sextet at $12 \mathrm{~K}$. Dragieva et al. [6,7] have suggested that the doublet partly is due to hydride formation. However, our studies show that the doublet is due to oxidation of the surface of the particles. The Mössbauer parameters of the oxide depends on the overall boron content of the particles. The results therefore suggest that the passivation layer consists of a poorly crystallized ironboron oxide.

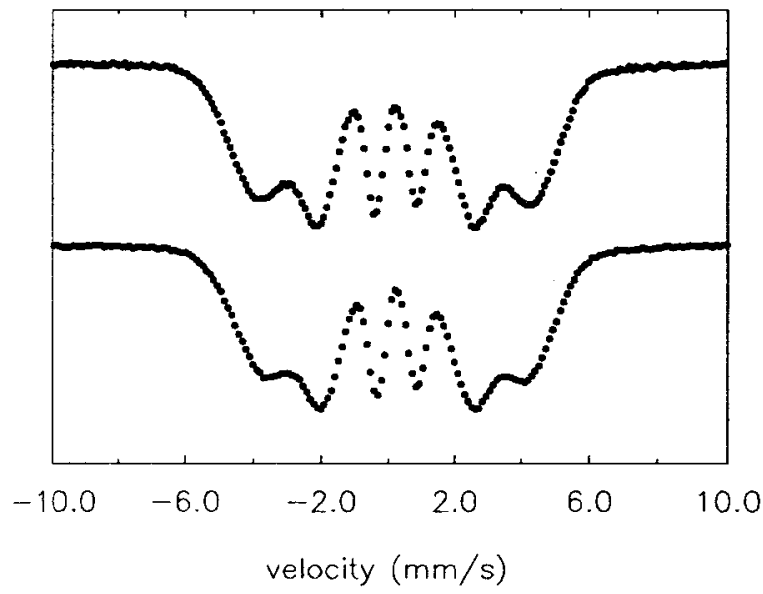

Fig. 1. Mössbauer spectra of amorphous Fe-B prepared by chemical reduction (addition of 200 $\mathrm{cm}^{3} 0.1 \mathrm{M} \mathrm{NaBH}_{4}$ to $500 \mathrm{~cm}^{3} 0.04 \mathrm{M} \mathrm{FeSO}_{4}$ ). Upper spectrum using an addition rate of 11.2 $\mathrm{cm}^{3} / \mathrm{min}$; lower spectrum at a rate of $39.9 \mathrm{~cm}^{3} / \mathrm{min}$.
The detailed mechanisms of alloy formation are still unknown. Early studies demonstrated that $\mathrm{pH}$ of the reacting solution is important by influencing the boron content of the alloys [4]. More recent studies have focused on the importance of the addition rate of the reductant. At $\mathrm{pH} 5$ the reaction changes from $\mathrm{H}^{+}$consuming to $\mathrm{OH}^{-}$consuming with increasing addition rate, but the boron content in the particles is nearly constant $(30 \pm 2$ at. \% B). We have prepared a series of samples at pH 5 using different addition rates. Mössbauer spectroscopy was used to probe the local environment of the iron atoms. The spectra show a decreasing resolution of lines $1,2,5$, and 6 with increasing addition rate (see e.g. Fig. 1) indicating broader distributions in hyperfine parameters. Thus the results indicate that amorphous alloys with different microstructures can be prepared by varying the addition rate.

[1] J. van Wonterghem, S. Mørup, C.J.W. Koch, S.W. Charles, and S. Wells, Nature 322 (1986) 622.

[2] S.G. Kim and J.R. Brock, J. Coll. Interface Sci. 116 (1987) 431

3] L. Yiping, G.C. Hadjipanayis, C.M. Sorensen, and K.J. Klabunde, J. Magn. Magn. Mater. 79 (1989) 321

[4] S. Linderoth and S. Mørup, J. Appl. Phys. 69 (1991) 5256.

[5] S. Linderoth, Hyp. Int. 68 (1991) 107.

[6] I. Dragieva, M. Slavcheva, D. Buchkov, and D. Mehandjiev, J. Magn. Magn. Mater. 89 (1990) 75.

[7] S. Nikolov, I. Dragieva, and A. Buchkov, AIP-231, NY, 1991, p. 294. 